\title{
Unnes Journal of Public Health
}

http://journal.unnes.ac.id/sju/index.php/ujph

\section{HUBUNGAN LINGKUNGAN FISIK DENGAN KEBERADAAN JENTIK AEDES PADA AREA BERVEGETASI POHON PISANG}

\section{Susanti ${ }^{\bowtie}$, dan Suharyo}

Fakultas Kesehatan Universitas Dian Nuswantoro, Semarang, Indonesia.

\section{Info Artikel}

Sejarah Artikel:

Diterima Juli 2017

Disetujui September 2017

Dipublikasikan Oktober 2017

\section{Keywords:}

Presence of Larvae; $p H$ Level;

Water Volume; Humidity;

Banana Tree Species.

\begin{abstract}
Abstrak
Profil Kesehatan Dinas Kota Semarang tahun 2016 menunjukkan bahwa ABJ di wilayah kerja Puskesmas Halmahera $83,00 \%$ masih tergolong rendah yaitu masih di bawah target nasional $\geq 95 \%$. Terdapat area dengan vegetasi pohon pisangg yang rapat pada wilayah tersebut. Penelitian ini bertujuan untuk mengetahui hubungan antara tingkat $\mathrm{pH}$, volume air, kelembaban dan jenis pohon pisang dengan keberadaan jentik Aedes aegypti di wilayah kerja puskesmas Halmahera Kota Semarang tahun 2017. Penelitian ini menggunakan metode observasional analitik kuantitatif dengan pendekatan cross sectional, data primer dan data sekunder diolah dan dianalisis menggunakan uji statistik Chi Square. Sampel yang digunakan berjumlah 100 pelepah. Hasil penelitian menunjukkan bahwa terdapat hubungan antara volume air $(\mathrm{p}=0,023)$ dan kelembaban $(\mathrm{p}=0,0001)$ dengan keberadaan jentik, serta tidak ada hubungan antara tingkat $\mathrm{pH}(\mathrm{p}=0,153)$ dan jenis pohon pisang $(\mathrm{p}=0,493)$ dengan keberadaan jentik.
\end{abstract}

\section{Abstract}

Health Profile of Semarang City Office in 2016 told that ABJ (larvae presence free number) in work Halmahera Health Center area was $83.00 \%$. It was below the national target of $\geq 95 \%$. This study purposed to know the relationship between $p H$ level, water volume, humidity and banana tree species with the presence of Aedes aegypti larvae in Halmahera Health Center area in 2017. This research used quantitative analytic observational method with cross sectional approach. Data were processed and analyzed using Chi Square test. The samples were 100 midribs. The results showed that there was correlation between water volume $(p=0,023)$ and humidity $(p=0.0001)$ with larvae presence, whereas there was no correlation between $p H$ level $(p=0,153)$ and banana tree species $(p=0,493)$ larvae presence.

(C) 2017 Universitas Negeri Semarang
pISSN 2252-6781

eISSN 2584-7604

Fakultas Kesehatan Universitas Dian Nuswantoro,

Jl. Nakula I No. 5-11, Semarang

E-mail: 411201301751@mhs.dinus.ac.id 


\section{PENDAHULUAN}

Demam berdarah dengue atau biasa dikenal dengan DBD adalah salah satu jenis penyakit menular yang menimbulkan keresahan di masyarakat, karena penularan penyakit demam berdarah berjalan dengan cepat dan juga dapat mengakibatkan kematian dalam waktu yang singkat (WHO, 2009). Angka kasus kejadian penyakit Demam Berdarah Dengue mengalami peningkatan secara drastis dalam waktu beberapa tahun terakhir. Penyebaran kasus DBD ini hampir menyebar di seluruh dunia. Lebih dari 2,5 milyar penduduk dunia $40 \%$ nya mengalami resiko DBD (Badrah \& Hidayah, 2011)

Penyakit DBD ini sangat dipengaruhi oleh beberapa faktor diantaranya yaitu lingkungan dan perilaku manusia, karena masih rendahnya kesadaran masyarakat untuk melaksanakan kegiatan PSN sehingga membuat tempat perindukan nyamuk semakin banyak. Dengan kondisi cuaca yang tidak selalu stabil dan curah hujan yang tinggi pada musim penghujan merupakan sarana untuk tempat perkembangbiakannya nyamuk Aedes aegypti yang cukup mendukung. Angka bebas jentik di Indonesia pada tahun 2011 sebesar 76,2\% dan meningkat pada tahun 2012 sebesar 79,3\% sedangkan pada tahun 2013 ada sedikit peningkatan yaitu 80,09\%. Naik turunnya angka bebas jentik di Indonesia setiap tahunnya belum mencapai target Nasional yang telah ditetapkan.

Kejadian DBD dipengaruhi oleh kepadatan populasi jentik Aedes aegypti. Keberadaan jentik vektor DBD sangat tergantung dari keberadaan tempat perindukan nyamuk (breeding place) Aedes aegypti. Tempat yang bagus untuk perindukan nyamuk Aedes aegypti adalah natural container (tempat perindukan alami), seperti lubang di pohon, batok kelapa, dan pada jenis perindukan pohon pisang atau lubang brudding di batu artificial container (tempat perindukan buatan) seperti bak mandi, ember, kaleng bekas, botol, drum, atau toples dan pelepah pohon pisang (Kusuma dan Sukendra, 2016). Diketahui bahwa sumur (natural container) dan gentong (artificial container) merupakan tempat yang paling bagus biasanya dalam perkembangbiakan nyamuk Aedes aegypti (WHO, 2009). Wilyah kerja Puskesmas Halmahera memiliki ABJ rendah (83\%) menurut Profil Kesehatan Kota Semarang tahun 2016 dan banyak ditemukan pohon pisang tumbuh bergerombol. Berdasarkan uraian di atas, peneliti merasa penting untuk melakukan penelitian dari semua tempat perindukan nyamuk demam berdarah di wilayah kerja Puskesmas Halmahera Semarang, mengenai hubungan lingkungan fisik seperti tingkat $\mathrm{pH}$, volume air, kelembaban udara dan jenis perindukan pohon pisang dengan keberadaan jentik
Aedes aegypti di wilayah kerja Puskesmas Halmahera kota Semarang tahun 2017.

Aedes aegypti adalah jenis nyamuk penyebab penyakit DBD sebagai pembawa utama (primary vektor) virus dengue (WHO, 2009). Nyamuk jenis Aedes aegypti yang sudah menghisap virus dengue sebagai penular penyakit demam berdarah. Adanya penularan itu karena setiap nyamuk itu mengggit, nyamuk tersebut menghisap darah yang aan menghasilkan air liur dengan bantuan alat tusuknya supaya darahnya yang telah dihisap tidak dapat membeku. Nyamuk Aedes aegypti mempunyai persebaran dengue yang sangat luas hampir semua mencakup daerah yang tropis maupun subtropis diseluiruh dunia. Hal ini membawa siklus persebarannya baik di desa, kota maupun disekitar daerah penduduk yang padat (Silalahi, 2014). Beberapa penularan penyakit DBD yang disebabkan nyamuk Aedes aegypti yaitu mulai dari perilaku menggigit, perilku istirahat dan juga jangkauan terbang untuk disebarkannya virus dengue (Yudastuti, 2005).

Nyamuk Aedes aegypti siklus hidupnya mempunyai empat fase yaitu dari mulai telur, jentik, pupa, sampai menjadi nyamuk dewasa. Nyamuk jenis ini mempunyai siklus hidup sempurna. Spesies ini meletakkan telurnya pada kondisi permukaan air yang bersih secara individual. Telur yang memilki bentuk elips warnanya hitam dan juga terpisah satu dengan yang lain. Telurnya dapat menetes dalam waktu 1-2 hari kemudian akan berubah jentik.

Terdiri dari 4 tahap didalam perkembangannya jentik yang dikenal sebagai instar. Perkembangan instar 1 ke instar 4 membutuhkan waktu kirakira 5 hari. Selanjutnya untuk sampai instar ke 4, larva ini berubah menjadi pupa yang dimana jentik tersebut telah memasuki masa dorman. Pupa dapat bertahan selama 2 hari sebelum nyamuk dewasa keluar dari pupa. Perkembangan mulai dari telur hingga menjadi nyamuk dewasa membutuhkan waktu selama 8 hingga 10 hari, namun juga bisa lebih lama jika kondisi lingkungan yang tidak mendukung (WHO, 2009).

Berikut merupakan morfologi nyamuk Aedes aegypti yaitu yang pertama telur Aedes aegypti setiap kali bertelur nyamuk betina dapat mengeluarkan kurang lebih 100 butir telur dengan berukuran 0,7 mm per butir. Ketika pertama kali dikeluarkan oleh induk nyamuk, telur Aedes aegypti berwarna putih dan juga lunak. Kemudian telur tersebut menjadi warna hitam dan keras. Telur tersebut dengan bentuk ovoid meruncing dan sering diletakkan satu per satu. Induk nyamuk biasanya meletakkan telurnya pada dinding tempat penampungan air seperti lubang batu, gentong, lubang pohon, dan bisa jadi di pelepah pohon pisang diatas garis air (WHO.2009). Kedua Jentik Aedes aegypti memiliki sifon yang be- 
sar dan pendek serta hanya terdapat sepasang sisik subsentral dengan jarak lebih dari seperempat bagian dari pangkal sifon. Dapat dibedakan jentik Aedes aegypti dengan genus yang lain yaitu dengan ciri-ciri tambahan seperti sekurang-kurangnya ada tiga pasang yang satu pada sirip ventral, antenna tidak melekat penuh dan tidak ada setae yang besar pada toraks. Ciri ini dapat membedakan jentik Aedes aegypti dari umumnya genus Culicine kecuali Haemagogus dari Amerika Selatan. Karakteristik jentik Aedes aegypti yaitu bergerak aktif dan lincah di dalam air bersih dari bawah ke permukaan untuk mengambil udara nafas lalu kembali lagi kebawah, posisinya membentuk 45 derajat, jika istirahat jentik terlihat agak tegak lurus dengan permukaan air (WHO, 2009). Ketiga Pupa Aedes aegypti Kepompong atau stadium pupa adalah fase terakhir siklus nyamuk yang berada di dalam lingkungan air. Pada stadium ini memerlukan waktu sekitar 2 hari pada suhu optimum atau lebih panjang pada suhu rendah. Fase ini yaitu periode masa atau waktu tidak makan dan sedikit bergerak (Silalahi, 2014). Dan yang keempat Aedes aegypti dewasa mempunyai ukuran yang sedang dengan warna tubuh hitam kecoklatan. Pada tubuh dan juga tungkainya ditutupi oleh sisik dengan garis-garis putih keperakan. Pada bagian punggung tubuh tampak ada dua garis yang melengkung vertikal yaitu bagian kiri dan bagian kanan yang menjadi ciri-ciri dari spesies tersebut. Pada umumnya, sisik tubuh nyamuk mudah rontok atau lepas sehingga menyulitkan identifikasi pada nyamuk tua. Ukuran dan warna nyamuk jenis ini terlihat sering berbeda antar populasi, tergantung pada kondisi di lingkungan dan juga nutrisi yang didapat nyamuk selama masa perkembangan.

Tempat Peridukan nyamuk Aedes aegypti (Breeding Place) yaitu tempat penampungan air yang sedikit terkontaminasi atau tempat penampungan air yang mengandung air jernih. Tempat yang tidak tekena sinar matahari langsung lebih disukai Aedes aegypti dan pada tempat perindukan yang berkontak langsung dengan tanah tidak dapat bertahan hidup (Silalahi, 2014).

Lingkungan fisik yang menjadi pengaruh ekologi nyamuk Aedes aegypti sebagai berikut Tingkat $\mathrm{pH}$ air menjadi pengaruh pada perkembanganbiakan nyamuk. Hal ini $\mathrm{pH}$ air perindukan berpengaruh pada pertumbuhan dan juga perkembangan Aedes aegypti pra dewasa, dan pada keadaan $\mathrm{pH}$ asam dilihat lebih rendah daripada $\mathrm{pH}$ basa yakni penurunan $\mathrm{pH}$ berarti bisa menghambatnya pertumbuhan larva menjadi nyamuk dewasa, ini berarti penurunan $\mathrm{pH}$ air pada perindukan terkait dengan pembentukannya enzim sitokrom oksidase dimana pada tubuh larva memiliki fungsi untuk proses metabolisme. Tinggi rendahnya proses pem- bentukan enzim ini dipengaruhi oleh kadar oksigen yang telah larut di dalam air. Kadar oksigen yang telah larut semakin tinggi ketika berada pada kondisi asam ( $\mathrm{pH}$ rendah), sedangkan pada kondisi basa ( $\mathrm{pH}$ tinggi) kadar oksigen yang telah larut semakin rendah. Pada suasana asam, maka pertumbuhan pada mikroba akan berjalan dengan pesat, sehingga oksigen yang dibutuhkan akan meningkat. Akibatnya semakin berkurangnya kadar oksigen yang terlarut. Kondisi tersebut bisa di indikasikan menjadi pengaruh pembentukan enzim sitokrom oksidase. Enzim tersebut adalah enzim yang mempengaruhi perkembangan dan pertumbuhan Aedes Aegypti pra dewasa (WHO, 2009). Volume air yang dibutuhkan untuk perkembangbiakannya nyamuk Aedes aegypti minimal tiga mililiter atau biasanya tempat perindukan yang disukai adalah air tanah yang di tampung dalam kontainer (air yang tidak berhubungan langsung dengan tanah) (WHO, 2009). Kelembaban di udara ketika berada pada suhu 20 derajat celcius dengan kelembaban nisbih 60\% dapat mempengaruhi usia nyamuk, yaitu untuk usia nyamuk betina biasanya sampai 101 hari dan untuk usia nyamuk jantan sampai 35 hari. Kemudian kelembaban nisbih 55\% usia nyamuk betina berubah menjadi 88 hari sedangkan pada nyamuk jantan hanya 50 hari. Maka dilihat dari menurunnya kelembaban udara sampai kurang 50\% umur nyamuk akan menjadi pendek. Berdasarkan kondisi tersebut nyamuk tidak akan menjadi vektor, karena tidak memiliki waktu yang cukup untuk memindahkannya virus dari lambung ke kelenjar ludah (WHO, 2009).

Berikut jenis pohon pisang yang terdapat di semarang yaitu antara lain sebagai berikut yaitu pertama Pisang Raja Pisang ini mempunyai ciriciri dengan bentuk buah yang menjuntai ke langit sedangkan kulit pisang raja ini cukup tebal dan agak kasar. Apabila buah pisang raja ini sudah mulai matang maka warna daging akan berubah warna menjadi kuning keemasan. Buah pisang raja ini akan menimbulkan bau harum yang menggoda selera selama buah pisang matang. Bau harum tersebut merupakan keunggulan yang ada pada pisang raja, karena tidak ditemukan pada pisang lain dan tidak hanya itu pisang raja ini juga memilki ukuran yang sempurna. Ukuran batang pohon pisang raja besar, memiliki ukuran daun yang lebar serta bentuk pelepah daun pisang lebar. Pisang raja bisa tumbuh mencapai ketinggian 4 meter dengan ratarata pohon pisangnya bergerombol. Kedua Pisang kapok ini mempunyai keunikan tersendiri yaitu pisang berwarna hijau disaat muda dan matangnya sehingga tidak terdapat perbedaan seperti pisang yag lainnya. Kulit pisang kapok ini cukup tebal dan ketika sudah mulai matang warna daging pada buah pisang kapok ini berubah menjadi warna krem 
yang pada asalnya berwarna putih. Biasanya pisang kapok ini bisa direbus atau digoreng selain itu juga bisa diolah menjadi bahan dalam pembuatan kue atau bolu. Pisang kapok memiliki pelepah pisang kecil dan daun yang tidak besar seperti pisang raja. Bagian batang semu dari pisang kepok ini memiliki lapisan-lapisan yang tidak terlalu tebal sehingga batang semu dari pisang kapok ini kecil. Pisang mas ini sudah dikenal banyak orang pada umumnya. Selain namanya yang unik, pisang ini juga mempunyai ciri warna yaitu kuning keemasan. Kulit pisang mas ini tipis dan mempunyai tekstur buah yang padat dan tidak terlalu besar. Sehingga biasanya pisang mas ini dijadikan sebagai pencuci mulut atau makanan penutup. Bentuk pelepah pisang mas kecil, lebih kecil dari pada pisang kapok. Memiliki bentuk daun yang ukurannya tidak sebesar ukuran daun dari pisang kapok. Pisang mas memiliki batang semu yang tidak begitu kuat sehingga ketika pisang mas ini berbuah harus diberikan penyangga supaya batang semunya tidak patah sebelum buahnya masak.

\section{METODE}

Penelitian ini menggunakan jenis penelitian observasional (survei) dengan pendekatan cross sectional. Dimana variabel bebasnya adalah tingkat $\mathrm{pH}$, volume air, kelembaban, dan jenis perindukan pohon pisang, sedangkan variabel terikat yaitu keberadaan jentik. Populasi penelitian ini adalah semua jenis perindukan pohon pisang pada pelepah yang terdapat air yang ada di wilayah kerja puskesmas Halmahera semarang. Sampel dalam penelitian berjumlah 100 pelepah yang terdapat air menggunakan teknik tidak acak dengan menggunakan kuota sampel.

Instrumen dan cara pengambilan data yaitu untuk mendapatkan data kelembaban dilakukan dengan menggunakan alat hygrometer dengan cara menyalakan alatnya maka secara otomatis akan muncul nilai atau indikasi perubahan kelembaban udara dan suhu pada lingkungan tersebut, untuk mendapatkan data $\mathrm{pH}$ dilakukan dengan cara menggunakan indikator universal dengan mencelupkan pada pelepah yang terdapat air untuk men- getahui keasaman atau kebasaan pada suatu larutan, dan data volume yaitu dengan mengambil air yang terdapat pada pelepah dengan menggunakan pipet dan diukur dengan gelas ukur untuk diketahui jumlah volume air.

Analisis data yang digunakan dalam penelitian ini yaitu metode observasional analitik kuantitatif dengan pendekatan cross sectional, data primer dan data sekunder diolah dan dianalisis menggunakan uji statistik Chi Square.

\section{HASIL DAN PEMBAHASAN}

\section{Hubungan Antara Tingkat pH Dengan Ke- beradaan Jentik Aedes aegypti}

Hasil uji yang dilakukan menunjukkan bahwa secara statistic tidak ada hubungan antara tingkat $\mathrm{pH}$ dengan keberadaan jentik Aedes aegypti di wilayah kerja puskesmas Halmahera kota semarang dengan $p$ value 0,153 ( $p$ value $>0,05$ ). Berdasarkan hasil penelitian dapat diketahui bahwa tingkat $\mathrm{pH}$ optimal ( $\mathrm{pH} 7-8$ ) berpotensi menjadi tempat perkembangbiakan nyamuk Aedes aegypti yaitu pada bahwa persentase yang optimal tingkat $\mathrm{pH}$ yang terdapat jentik sebesar 28,8\% lebih besar dari pada yang tidak optimal yaitu $14,8 \%$. Sedangkan pada penelitian lain diketahui bahwa dari semua sumur gali menyatakan bahwa tingkat keasaman air pada kondisi netral sehingga $\mathrm{pH}$ air sumur gali yang netral berpotensi menjadi tempat perkembangbiakan nyamuk. Pengaruh $\mathrm{pH}$ air perindukan 7 , lebih banyak terdapat jentik nyamuk daripada $\mathrm{pH}$ asam atau basa (Fauziah, 2012). Tingkat $\mathrm{pH}$ dalam penelitian ini tidak berhubungan karena secara statistik bukti belum mencukupi padahal padahal pada $\mathrm{pH}$ optimal berpotensi menjadi tempat perkembangbiakan nyamuk. Rata-rata kandugan air yang terdapat di pelepah pisang berasal dari air hujan atau tetesan embun. Rata-rata air hujan memiliki $\mathrm{pH}$ normal. Adanya kandungan $\mathrm{pH}$ yang tidak optimal bisa dipengaruhi dari lingkungan yang memberikan sifat asam atau basa pada air yang berada di pisang tersebut.

Kecil atau besarnya $\mathrm{pH}$ bisa menjadi pengaruh kuat tidaknya jentik nyamuk untuk bisa berta-

Tabel 1. Hubungan Antara Tingkat pH Dengan Keberadaan Jentik Aedes aegypti

\section{Distribusi Frekuensi}

\begin{tabular}{lllllll} 
Tingkat $\mathbf{p H}$ & \multicolumn{2}{l}{ Ada Jentik } & \multicolumn{2}{l}{ Tidak Ada Jentik } & \multicolumn{2}{l}{ Total } \\
& $\mathbf{f}$ & $\mathbf{( \% )}$ & $\mathbf{f}$ & $\mathbf{( \% )}$ & $\mathbf{f}$ & $\mathbf{( \% )}$ \\
\hline $\begin{array}{l}\text { Optimal } \\
\text { Tidak Optimal }\end{array}$ & 21 & 28.8 & 52 & 71,2 & 73 & 100 \\
& 4 & 14,8 & 23 & 85.2 & 27 & 100 \\
\hline
\end{tabular}


han hidup, karena jentik nyamuk bisa hidup pada $\mathrm{pH}$ yang optimal dengan rentang 7-8.

\section{Hubungan Antara Volume Air Dengan Ke- beradaan Jentik Aedes aegypti}

Hasil uji yang dilakukan menunjukan bahwa secara statistik terdapat hubungan antara volume air dengan keberadaan jentik Aedes aegypti di wilayah kerja Puskesmas Halmahera kota Semarang. Diketahui bahwa persentase volume air yang terdapat jentik pada volume air yang tidak potensial $(82,5 \%)$ lebih besar dari pada volume air yang potensial $(62,2 \%)$. Volume yang potensial untuk jentik nyamuk Aedes aegypti bisa bertahan hidup berkisar $3 \mathrm{~mm}$ atau lebih (Santi, et al; 2015). Sedangkan pada volume air pelepah yang kurang dari $3 \mathrm{~mm}$ menjadi tempat sarang yang kurang potensial untuk perkembangbiakan nyamuk Aedes aegypti, banyak sedikitnya volume dipengaruhi oleh bentuk dan lebar dari pelepah pisang. Pelepah pisang yang menjadi obyek penelitian ada 3 jenis. Yang mana 3 jenis ini memiliki lebar dan panjang pelepah yang berbedabeda. Dari 100 pohon pisang yang diamati terdapat beberapa pohon pisang yang hanya memilki sedikit airnnya. Rata-rata pelepah pohon pisang yang memiliki volume air untuk dijadikan sarang nyamuk Aedes aegypti adalah pisang kepok. Pisang kepok disamping memiliki pelepah besar dan cekungannya dalam juga terdapat daun yang lebar sehingga pada saat hujan air tersebut dapat mengenai daun, sehingga air secara otomatis akan mengucur ke cekungan yang dalam. Sedangkan pada hasil penelitian lain menyatakan bahwa tidak ada perbedaan yang bermakna antara kontainer yang volume airnya sedikit dan kontainer yang volume airnya banyak untuk dapat bertelur dan berkembang biak pada genangan air yang tertampung.
Hubungan Antara Kelembaban Udara Dengan Keberadaan Jentik Aedes aegypti

Hasil uji yang dilakukan menunjukkan bahwa secara statistik terdapat hubungan antara kelembaban udara dengan keberadann jentik nyamuk Aedes aegypti di wilayah kerja puskesmas Halmahera kota semarang. Pada umumnya jentik nyamuk Aedes aegypti bisa bertahan hidup pada kelembaban udara yang tidak terlalu kering dan juga terlalu lembab. Jentik nyamuk bisa bertahan hidup di tingkat kelembaban yang sesuai dengan suhu udara yang tidak terlalu dingin dan teralu panas. Dapat diketahui bahwa persentase kelembaban udara yang terdapat jentik pada kategori potesnsial yaitu $45,5 \%$ lebih besar dari pada kategori tidak potensial yaitu $8,9 \%$. Nilai rentang kategori tidak baik adalah $<75 \%$. Sedangkan dari hasil tersebut dan dihitung berdasarkan hasil uji statistik Chi Square di peroleh $p$ value $=0.0001$ berarti bahwa ada hubungan antara kelembaban udara dengan keberadaan jentik di Wilayah kerja Puskesmas Halmahera Kota Semarang. Sedangkan pada penelitian lain diketahui bahwa kelembaban rumah menunjukkan kategori baik bagi perkembangbiakan jentik nyamuk (70-90\%) sebesar $56,3 \%$ dibandingkan dengan rumah yang kurang baik bagi perkembangbiakan nyamuk yakni $43,7 \%$ (Novitasari \& Sugiyanto, 2014; Alma, 2014; Winarsih, 2013).

Hubungan Antara Jenis Perindukan Pohon Pisang Dengan Keberadaan Jentik Aedes aegypti

Hasil penelitian dengan menggunakan uji statistik Chi Square antara jenis perindukan pohon pisang dengan keberadaan jentik Aedes aegypti di wilayah kerja puskesmas Halmahera kota semarang dengan $p$ value 0,493 ( $p$ value $>0,05$ ) yang berarti tidak ada hubungan antara jenis perindukan pohon pisang dengan keberadaan jentik. Dalam peneliti-

Tabel 2. Hubungan Antara Volume Dengan Keberadaan Jentik Aedes aegypti

\begin{tabular}{|c|c|c|c|c|c|c|}
\hline \multirow{3}{*}{ Volume } & \multicolumn{6}{|c|}{ Distribusi Frekuensi } \\
\hline & \multicolumn{2}{|c|}{ Ada Jentik } & \multicolumn{2}{|c|}{ Tidak Ada Jentik } & \multicolumn{2}{|c|}{ Total } \\
\hline & f & (\%) & f & $(\%)$ & f & $(\%)$ \\
\hline Potensial & 14 & 37,8 & 23 & 62,2 & 37 & 100 \\
\hline Tidak Potensial & 11 & 17,5 & 52 & 82,5 & 63 & 100 \\
\hline
\end{tabular}

Tabel 3. Hubungan Antara Kelembaban Udara Dengan Keberadaan Jentik

\begin{tabular}{lllllll}
\hline & \multicolumn{2}{l}{$\begin{array}{l}\text { Distribusi Frekuensi } \\
\text { Kda Jentik }\end{array}$} & \multicolumn{2}{l}{ Tidak Ada Jentik } & Total & \\
& f & $\mathbf{( \% )}$ & $\mathbf{f}$ & $\mathbf{( \% )}$ & $\mathbf{f}$ & $\mathbf{( \% )}$ \\
\hline Potensial & 20 & 45,5 & 24 & 54,5 & 44 & 100 \\
Tidak Potensial & 5 & 8,9 & 51 & 91,1 & 56 & 100 \\
\hline
\end{tabular}


Tabel 4. Hubungan Antara Jenis Perindukan Pohon Pisang Dengan Keberadaan Jentik Aedes aegypti

\begin{tabular}{lllllll}
\hline & \multicolumn{2}{l}{ Distribusi Frekuensi } & & \multicolumn{2}{l}{ Tidak Ada Jentik } \\
Jenis Pisang & Ada Jentik & & \multicolumn{2}{l}{ Total } \\
& $\mathbf{f}$ & $\mathbf{( \% )}$ & $\mathbf{f}$ & $\mathbf{f}$ & $\mathbf{( \% )}$ \\
\hline Pisang Mas & 15 & 27,3 & 40 & 72,7 & 55 & 100 \\
Pisang Kepok & 5 & 31,2 & 11 & 68,8 & 16 & 100 \\
Pisang Raja & 5 & 17,5 & 24 & 82,8 & 29 & 100 \\
\hline
\end{tabular}

an ini disebutkan bahwa jenis perindukan pohon pisang yang terdapat jentik terbesar yaitu pisang mas yakni dengan persentase $27,3 \%$ sedangkan pada pisang raja $(17,5 \%)$ dan pisang kepok $(31,2 \%)$. Hasil dari penelitian ini berbeda dengan penelitian lain bahwa tempat perindukan nyamuk seperti bak mandi, ember, dispenser, kulkas, botol/kaleng bekas dan ban bekas yang menjadi tempat berpotensi untuk bertelur dan perkembangbiakan nyamuk yaitu sebesar $(87,5 \%)$ berarti bahwa yang menjadi tempat berpotensi untuk perkembangbiakan nyamuk adalah pada tempat perindukan artificial (buatan). Akan tetapi pada penelitian ini tempat perindukan artificial yang paling banyak ditemukan jentik adalah dispenser yaitu sebesar $57,14 \%$ dan penelitianpenelitian terdahulu membuktikan hal tersebut memang berkorelasi dengan keberadaan jentik (Putri, 2015; Winarsih, 2013; Yudastuti, 2005).

\section{SIMPULAN}

Sebagian besar jenis pisang yang dteliti masuk kedalam kategori jenis pisang yang paling banyak ditemukan yaitu pisang mas sebanyak (55\%), besar kategori $\mathrm{pH}$ dengan $\mathrm{pH}$ optimal (73\%), besar data yang didapat dalam kategori volume dengan hasil volue tidak baik (61\%), besar kategori kelembaban dengan kelembaban tidak baik (56\%).

Tidak ada hubungan antara tingkat $\mathrm{pH}$ dengan keberadaan jentik $(\mathrm{p}=0,153)$, terdapat hubungan antara volume dengan keberadaan jentik $(p=0,029)$. Ada hubungan antara kelembaban udara dengan keberadaan jentik ( $\mathrm{p}=0,0001)$ Tidak ada hubungan antara jenis perindukan pohon pisang dengan keberadaan jentik $(\mathrm{p}=0,493)$.

\section{DAFTAR PUSTAKA}

Alma, L. R. 2014. Pengaruh Status Penguasaan Tempat Tinggal dan Perilaku PSN DBD terhadap Keberadaan Jentik di Kelurahan Sekaran Kota Semarang. Unnes Journal of Public Health, 3 (3).
Badrah \& Hidayah. 2011. Hubungan Antara Tempat Perindukan Nyamuk Aedes Aegypti Degan Kasus Demam Berdarah Dengue di Kelurahan Penajan Kecamatan Penajan Pasar Kabupaten Pasar Utara. J. Trop. Pharm. Chim. (Indonesia), 1 (2).

Fauziyah, N. F. 2012. Karakteristik Sumur Gali dan Keberadaan Jentik Nyamuk Aedes aegypti. Jurnal Kesehatan Masyarakat (KEMAS), 8 (1): 81-87.

Kusuma, A. P., Sukendra, D. M. 2016. Analisis Spasial Kejadian Demam Berdarah Dengue Berdasarkan Kepadatan Penduduk. Unnes Journal of Public Health, 5 (1): $48-56$.

Mubarokah, R., Indarjo, S. 2013. Upaya Peningkatan Angka Bebas Jentik (ABJ) DBD melalui Penggerakan Jumantik. Unnes Journal of Public Health, 2 (3).

Novitasari, I. dan Sugiyanto, Z. 2014. Hubungan Suhu, Kelembaban Rumah dan Perilaku Masyarakat tentang PSN dan Larvasidasi dengan Keberadaan Jentik Nyamuk Penular Demam Berdarah Dengue di RW 01 Kelurahan Sendangguwo Semarang. Semarang: Universitas Dian Nuswantoro.

Putri, I. A. 2015. Hubungan Tempat Perindukan dan Perilaku Pemberantasan Sarang Nyamuk dengan Keberadaan Jentik Aedes aegypti di Kelurahan Benda Baru Kota Tanggerang Selatan Tahun 2015. Jakarta: Universitas Islam Negeri Jakarta.

Santi, D., Budiyono, I., Wahyono, B. 2015. Faktor yang Berhubungan dengan Keberadaan Jentik Aedes Aegypti (Studi Kasus Di Kelurahan Sukorejo, Kecamatan Gunungpati, Kota Semarang Tahun 2014). Unnes Journal of Public Health, 4 (1).

Silalahi, L. 2014. Demam Berdarah--Penyebaran dan Penanggulangan. Jakarta: Litbang Departemen Kesehatan RI.

WHO. 2009. Dengue: guidelines, diagnosis, treatmen, prevention and control. New edition. France: WHO Press.

Winarsih, S. 2013. Hubungan Kondisi Lingkungan Rumah dan Perilaku PSN Dengan Kejadian DBD. Unnes Journal of Public Health, 2(1).

Yudastuti, R dan Anny, V. 2005. Hubungan Kondisi Lingkungan, Kontainer, dan Perilaku Masyarakat Dengan Keberadaan Jentik Nyamuk Aedes aegypti di Daerah Endemis Demam Berdarah Dengue Surabaya. Jurnal Ilmiah Kesehatan, 1 (2). 